9

\title{
Women Plantation Workers and Economic Crisis in Cameroon
}

\author{
Piet Konings
}

Managements of tea estates have often given preference to female labour over male labour, on the assumption that women were naturally more suited to plucking tea (they had 'nimble fingers'). They were also thought to be cheaper and more docile than men. This managerial preference proved to be problematic, however, when tea farming came to Africa. First, it was difficult to recruit a regular and adequate supply of female labour for the newly created tea estates. The subordination of women under customary patriarchal controls in African societies often formed a serious obstacle to female migration and wage employment. Second, it was difficult to establish managerial control over women in the labour process. African women proved less submissive than management had expected. They demonstrated an ability to protect their interests both individually and collectively (Konings 1995b; Stichter and Parpart 1988).

In this chapter I focus on women pluckers at the Tole Tea Estate, one of the estates owned by the Cameroon Development Corporation (CDC). ${ }^{l}$ The CDC is a large agro-industrial parastatal operating in the coastal area of Anglophone Cameroon. It was founded in 1946/7 for the purpose of developing and managing the approximately 100,000 hectares (ha) of estate lands which had been confiscated by the British Trusteeship Authority from German planters at the outbreak of the Second World War (Ardener, E. et al. 1960; Epale 1985; Konings 1993). Between $1946 / 7$ and $1985 / 6$, it virtually doubled its cultivated area from about 20,000 ha to $40,000 \mathrm{ha}$, with the aid of huge foreign loans. Today it is still the second largest employer in the country, surpassed only by the government itself. In the early $1950 \mathrm{~s}$ it employed about 25,000 workers. At present, it has about 14,000 permanent workers and a few thousand seasonal and casual workers. Its chief crops are rubber, palm oil, bananas and tea. The CDC owns three tea estates and now enjoys a monopoly on tea production in the country.

The construction of the Tole Tea Estate in 1954 marked a turning point in the history of the CDC. This was its first estate to produce tea. More important for the present analysis, it was the first estate to recruit predominantly female labour. In 
the first section below I examine what categories of women tended to sell their labour power to the estate management and how this relates to customary patriarchal controls in the local communities. In the second section I highlight the intensification of managerial control and exploitation of women pluckers during the present economic crisis. And in the final section I deal with the response of women pluckers to this severe crisis, showing that they have adopted various strategies to cope with the structural adjustment measures which have been planned and implemented by the management in close cooperation with the state-controlled trade union. What emerges from this study is that even during the economic crisis the management has failed to fully control the women pluckers in the labour process.

\section{Women Tea Pluckers at the Tole Tea Estate}

Upon the completion of the Tole Tea Estate, the management decided to employ women for plucking tea, the central activity in tea production. There were various reasons for this decision. Tea plucking had widely come to be identified as 'women's work'. Vast numbers of women had been recruited on tea estates in Asia and elsewhere on the assumption that female pluckers were more productive, more docile and cheaper than male pluckers. If women in Asia were plucking tea, why wouldn't women in Cameroon? Moreover, at the time the Tole Estate was opened, some women were already working on the CDC estates, mainly on a casual or seasonal basis. They were mostly the wives of estate workers, or women from the surrounding villages. Finally, the management was confronted with a serious shortage of male labour on the plantations during the fifties, due to the spread of non-estate coffee and cocoa production locally.

For a long time management efforts to recruit an adequate supply of permanent women pluckers proved disappointing. The recruitment drive formed a direct threat to customary patriarchal control over female labour. In 1952, shortly before the Tole Estate was constructed, Phyllis Kaberry published her classic study of women in the Bamenda Grassfields, the 'traditional' labour reserve for the coastal plantations. Throughout her book she highlights the contradictory position of women in society. While on the one hand, there is a general recognition that women play an indispensable role as child bearers and food producers, on the other hand, they are subordinated to patriarchal controls. These contradictions in women's position may not be as puzzling as they appear at first sight. Control over women's vital productive and reproductive labour constituted the basis of men's prestige, power and wealth in society. In a recent study of women in the Bamenda Grassfields, Goheen (1993: 250) observes:

Women grew the food crops and were expected to provide the necessities of dally life from therr farms Women's productive labour freed men to participate in (lucrative) trading 
networks; their reproductive labour increased the size of the household and thus the status and the labour force of the male head. Any surplus value women produced over and above that required for household needs and petty barter was in the hands of men, who retained all the profits.

Male elders and chiefs therefore had a vested interest in keeping women's productive and reproductive labour confined to their local communities, and they were inclined to resist female migration and wage employment.

Gradually, however, this patriarchal opposition could not forestall an increasing flow of female labour to the new estate: in 1988 the estate was employing 1,604 permanent workers, 63 per cent of them women. Some female workers are women who accompanied their husbands to the estate, but most are women without husbands, having escaped for one reason or another from the control of male elders in their local communities and eager to build up an autonomous existence (see Table 9.1). Some of these are young, single women who had no access to land, but were expected to work as unpaid labour on their family farms. The majority are older women who, following the dissolution of a marriage either by death or divorce, lost relatively secure usufruct rights. Rather than to become dependent on the family elders for their survival, they preferred to migrate to the estate, where they could be sure of a regular monthly wage income.

Women who seek employment on the estate are by and large illiterate, or at least poorly educated. Plantation labour is one of the rare employment opportunities in the capitalist sector for this category of women. Female tea estate workers therefore have a high stake in plantation labour, especially since most of them are not only 'husbandless' (Bryceson 1980), but also household heads with children to support. They are deeply dependent on their income from plantation work for the reproduction of their families. As a result, they tend to be highly committed to their jobs, becoming increasingly stabilized (cf. Safa 1979: 447-8). Over 60 per cent of the Tole women have been employed on the estate for more than ten years. This workforce stability is enhanced by the fact that most women maintain few close links with their region of origin. The 'husbandless' women in particular seem to have pretty much severed the ties with their home towns and villages. Their escape from patriarchal control generally prevents them from maintaining contact with their family members and gaining access to land at home. Their 'exitoption' from wage employment would be for the most part a switch to petty trade in the coastal urban centres, and not a return home. Even married female workers on the estate find it hard to keep up intensive contacts with their family members at home. Geographical distance and a six-day working week pose serious obstacles to regular communication. Many female workers visit their home towns only during the annual leave period, or on special occasions such as funerals of close kin. 
Table 9.1. Demographic Characteristics of Tole Women in 1988. Per Cent.

\begin{tabular}{lr}
\hline \hline Age & \\
15-25 years & 7.5 \\
$25-35$ years & 32.5 \\
$35-45$ years & 41.0 \\
$45-55$ years & 17.0 \\
55 years and older & 2.0 \\
& 100.0 \\
Marital Status & \\
single & 9.0 \\
married & 32.0 \\
widowed & 27.0 \\
divorced/separated & 25.0 \\
free union & 7.0 \\
& 100.0 \\
Educational Level & \\
illiterate & 78.0 \\
primary education & 20.5 \\
post-primary education & 1.5 \\
& 100.0 \\
Religion & \\
Christian & 94.0 \\
ancestral belief & 6.0 \\
& 100.0 \\
Years of Service & \\
O-5 years & 17.0 \\
5-10 years & 19.5 \\
10-15 years & 39.0 \\
25 years and above & 19.5 \\
& 5.0 \\
\hline & \\
& \\
&
\end{tabular}

Source Computed from data supplied by the estate office

The female labour force on the estate by no means forms a homogeneous group. One can observe distinct divisions within it, based mainly on education, occupation, marriage, or ethnic and regional origin. There is a division, for instance, between the vast majority of illiterate and poorly educated field workers and the tiny group of better educated clerical workers. The latter tend to look down on the field workers and treat them rudely when they visit the estate office or clinic. There is also a 
division between married and unmarried female workers. Unmarried women are relatively free from customary patriarchal controls, but they are still held in low regard, being labelled as 'loose women' or 'prostitutes'. Married female workers are more respected, yet they are subjected to considerable male controls. Some husbands insist that according to African tradition, women are responsible for the upkeep of the family; these men are likely to make very little financial contribution, spending their wages as they choose. Others, in particular men from the Bamenda Grassfields, go as far as to claim that they are traditionally entitled to their wives' wage income. One more division is on ethnic and regional lines. On the estate there is a clear divide between women from the Bamenda Grassfields and women from the coastal/forest region: 67 per cent of the women originate from various ethnic groups in the Bamenda Grassfields and 27 per cent from ethnic groups in the coastal/forest region. Although ethnic and regional heterogeneity forms a potential source of conflict, with rivalry being sparked by suspicions of favouritism in hiring and promotion or in disagreements with supervisors or co-workers, there has been little incidence of serious, extended ethnic clashes. Generally speaking, estate workers of different ethnic groups or regions live and work together peacefully. It has been the consistent policy of the management, as well as church and union leaders, to mobilize and organize workers on a multi-ethnic basis, and this policy seems to have created a certain measure of understanding and tolerance among the workers for each other's sociocultural background, and to have fostered bonds of companionship and friendship across ethnic boundaries. The general use of Pidgin English has also helped to overcome communication barriers between the various ethnic groups. The most important reason for this relative harmony, however, appears to be the sharing of similar living and working conditions on the estate, which is a classic example of an occupational community.

Finally, there is still another division between male and female workers on the estate. The root of this cleft is the pervasive ideology of male dominance. For example, the men expect the male-dominated management to give them preference over women when there is an opportunity for further training or promotion, and to fire female workers when there is a retrenchment exercise. They are reluctant to work under female supervision, and they regularly harass their female colleagues. There is also a persistent fear among the married men that wage employment will make their wives too 'headstrong' or independent.

Remarkably, these divisions within the Tole labour force have never kept the workers from engaging in common actions for the promotion of their interests. They display an ambivalent attitude towards plantation labour: they value it, since it provides them with a regular source of income; but they harbour an acute feeling of exploitation and subordination in the workplace. 


\section{Intensification of Managerial Exploitation and Control during the Economic Crisis}

As in other parts of the world (Loewenson 1992), estate workers in Cameroon receive low remuneration for their arduous work. What is more, female workers were initially paid less than male workers. Apparently the management wanted to implement the same system of unequal payment for men and women that prevailed on many other tea estates in Asia and Africa (Kurian 1982; Vaughan and Chipande 1986). This was justified on the spurious grounds that female workers needed less time (seven hours) to complete their daily task than did male workers (eight hours). In 1967, however, a Federal Labour Code was promulgated which prohibited employers from paying men and women differently for equal work, and the estate management then introduced equal rates of pay.

Prior to the economic recession, tea pluckers were earning an average net monthly wage of approximately FCFA $20,000-25,000{ }^{2}$ Some pluckers were unable to earn this much, however, mainly due to a linkage between the remuneration of workers and the system of task work prevailing on the plantations. Completion of the daily task set by the management entitled a worker to the daily basic wage; noncompletion was punished by pro-rata payment, a proportion of the wage equivalent to the proportion of the task completed.

The management has never denied that women receive low cash wages, but it continually stressed that the variety of non-cash benefits supplied by the corporation, such as accommodation, medical care, and a plot for food cultivation, supplement their incomes. Some remarks are in order here, however. The dwellings provided are very small and are in a deplorable state. The clinic lacks qualified personnel and suffers regular shortages of essential drugs. During my fieldwork I found that only 57 per cent of the female workers had been allocated land free of charge for food production. The remaining women had to hire land from local peasants.

The exploitation of women workers has intensified during the economic crisis that has been affecting the corporation since 1986/7. Between 1986/7 and 1990/1, the CDC suffered losses totalling about FCFA 19 billion. There is no doubt that the sharp fall in commodity prices on the world market was prımarily responsible for the virtual bankruptcy of the corporation. Nevertheless, other factors also contributed to the emergence and persistence of the crisis. First, there was the political elite's inability or unwillingness to control the imports of cheap tea, which caused CDC sales to stagnate in the domestic market. Second, there have been frequent reports of the managerial elite's involvement in massive embezzlement, reckless expenditure, waste and power struggles; small wonder that many estate workers did not believe the management would be capable of effectively combating the crisis (Konings 1995a). 
To save the company from total collapse, the CDC management and the statecontrolled trade union agreed to adopt a series of adjustment measures aimed at cost reduction and productivity increases. On 23 August 1987 they agreed upon a substantial intensification of task work. The daily quota required from tea pluckers was upped from 26 to $32 \mathrm{~kg}$ of green leaves. This was accompanied by a redoubled managerial crusade against 'undisciplined and unproductive' workers:

The corporation is required to meet certain standards of efficiency and to be self-supporting and profitable... That is why we have to be generally very strict on discipline and sanction any manifestation of laxity... Maximum efforts shall be required of employees so as to continue producing more at lower and lower cost; laxity and laissez faire which are characterized by an alarming rate of absenteeism and uncompleted tasks shall not be tolerated. Pilferage shall meet with maximum sanctions. ${ }^{3}$

As the corporation's financial position continued deteriorating, the management proposed further 'austerity' measures to the union leadership. Following negotiations a new agreement was signed on 6 January 1990 entailing drastic cuts in the wages and fringe benefits of all workers, amounting to some 30 to 40 per cent of their previous incomes. Henceforth the workers would be obliged to make substantial contributions towards the range of services which the corporation previously supplied free of charge, such as housing, water, electricity and medical facilities. The most draconian measure was the introduction of a compulsory savings scheme, forcing the workers to save at least 15 per cent of their basic wages and salaries to aid the corporation's recovery.

The union leadership had expected the workers' increased output and financial sacrifices to forestall, or at least minimize, any retrenchment. This proved wishful thinking. The management soon embarked on mass layoffs. Between 1987/8 and 1990/1, the labour force on the Tole Estate shrank from 1,604 to 974.

As a consequence of the various adjustment measures, women's position on the estate has deteriorated dramatically. They are compelled to work harder for a much lower reward. They experience immense difficulties in combining plantation work with their other productive and reproductive responsibilities. Owing to their increased workload on the estate, they must stay longer in the field. They now often lack time and energy to engage in additional income-generating activities, such as food production and trade, and to care for their children. The estate does provide a crèche and a nursery school, at a cost of FCFA 2,000 a month, but very few children attend them. Most women are dissatisfied with the services rendered there, and they prefer to use other methods of child care - relying, if possible, on their older children, relatives, friends or neighbours. The period of breast-feeding is the most problematic. The management does not allow the women to take their nursing children to the field, though a few women do it all the same. Usually women 
go home during breaks (if they are not too far away) to tend to their children or give them a quick feeding. It is not uncommon, however, to see other children bringing hungry babies to their resting mothers during breaks (DeLancey 1981). Last but not least, the women's employment on the estate has become insecure, due to the repeated reorganization measures.

\section{Response of Women Pluckers to the Economic Crisis}

The Tole women challenge the pervasive managerial assumption that female workers are more docile than males (Elson and Pearson 1984). From the outset the management had trouble controlling the women pluckers (Konings 1995b), and the Tole Estate quickly acquired a bad reputation in management circles. Time and again the CDC management was forced to admit that 'the Tole Tea Estate is one of the most troubled spots on the CDC plantations'4 and that 'output on the estate has remained almost pathetically low'. ${ }^{5}$

Management's apparent lack of control over women pluckers does not come as a complete surprise, for African women have persistently shown a capacity to protect their interests individually and collectively. Many accounts have revealed frequent conflicts between husbands and wives over land, labour and 'capital' (cf. Kaberry 1952). African women have regularly engaged in informal and collective modes of resistance to male abuse of power (Isaacman 1990). Individual informal actions have included refusal to cook or have sexual intercourse, withdrawal of domestic and agricultural labour, temporary or permanent return to the parental home, spreading gossip about their spouses, migration, calling in the supernatural, and manipulation of men. Collective actions of women have occurred in several African countries, including Cameroon (Ardener 1975; O'Barr 1984; Parpart 1988). Two such actions, known as anlu and fombuen, have been documented in the Bamenda Grassfields, the region of origin of most Tole Tea women (Nkwi 1985; Diduk 1989; Shanklin 1990). In essence these were manifestations of women's resistance against male abuse of power and against the colonial power's efforts to estabiish control over the means of production (land) and the labour process, thus forming a direct threat to women's food production and relatively autonomous work activities. Tole female pluckers have likewise proved capable of undertaking a whole range of actions against their subjection and exploitation in the labour process, including syndicalist, collective, and informal actions (Cohen 1980; Stichter 1985).

Similarly to other parts of the world (Elson and Pearson 1984; Pittin 1984; Ecevit 1991), women's involvement in trade union affairs at the Tole Estate has usually been low. They participate little in the decision-making process and rarely compete for office. This must be attributed mainly to their illiteracy, their lack of time due 
to multiple productive and reproductive responsibilities, and the union's patriarchal structure. Any support for the union has always been highly conditional and instrumental. If the union leadership and shop stewards act promptly and forcefully upon receipt of a complaint and 'deliver the goods', they can be sure of the women's support. Tole women have always admired militant trade union leadership. They massively joined the 1955 and 1966 general strikes of CDC workers called out by the union for an improvement in wages and conditions of service. Conversely, if the union leadership fails to represent the interests of the workers in general and the women in particular, Tole women have been inclined to circumvent the union. In particular, the establishment of state control over the union in 1972 touched off a crisis of confidence in the union leadership and shop stewards.

There is ample evidence, moreover, that the Tole women have sought alternative ways of defending their interests, notably by engaging in informal and collective actions, when they perceive that the union is unresponsive to their demands (Konings 1995b). Informal modes of labour resistance, such as insubordination, output restriction, unauthorized absence and theft, are obviously less visible and dramatic forms of protest than collective modes of resistance, but they occur almost daily on the estate. Collective actions such as strikes, riots, demonstrations and go-slows, are riskier in Cameroon, where the post-colonial state strives for 'total' control over civil society (Bayart 1979) and has virtually outlawed strikes since 1967 Strikes occur only as a last resort, when institutionalized procedures for settling conflicts between management and labour, such as joint negotiation and collective bargaining, are either absent or ineffective.

Interestingly, despite increasing state and management controls over the labour process, Tole women have continued to display a remarkable degree of militancy. They have engaged in a considerable number of informal and collective actions either to back up demands for improvement in wages, fringe benefits and incentive bonus schemes or to protest against increased control and exploitation. They have been most successful in resisting managerial efforts to raise the level of task work: plucking norms were hardly increased by the management in the period 1963-80. They have been least successful at removing authoritarian or overzealous managerial and supervisory staff from their posts. Their actions should not be judged only in terms of success or failure, of course. They should also be conceived as key opportunities for raising women's capacities for self-organization and self-confidence.

Given this long tradition of women's militancy on the estate, what was their reaction towards the severe economic crisis and adjustment measures?

Confronted with the close cooperation between management and union leadership in planning and implementing austere adjustment measures, the response of the women pluckers has been complex and varied. Some women have opted for a single strategy, others for several strategies, either simultaneous or consecutive. A growing number of women have become survival-oriented in the climate of 
insecurity. They are inclined to acquiesce in whatever economic recovery measures management may introduce, for the sake of keeping their job. They try to impress the management with above-average output, and they avoid conflicts with their supervisors. This tendency is fuelled by the fact that most Tole women do not maintain close links with their home area, thus lacking an easy 'exit-option'.

Some women still rely on the bargaining strength of the state-controlled trade union for the protection of their interests. But most women have lost whatever confidence they ever had in the union leadership. They tend to bypass the union and lodge their individual or collective complaints with the Labour Department, which is usually perceived by workers as a neutral intermediary between management and labour. This department is overburdened with work, often resulting in long delays in settling disputes.

Unexpectedly, the majority of the women continue to resort to both informal and collective protest actions. These are directed against their intensified exploitation and subordination manifest in managerial efforts to raise labour productivity by intensifying task work, to strengthen control over the labour process and to mınımize wages and other conditions of service. One can nevertheless observe a decline in the number of collective actions. This is understandable, for in times of economic crisis strikes are more likely to elicit severe managerial reprisals, in the form of summary dismissals, than in times of prosperity. Significantly, the decline of collective actions appears to have been compensated by an increase in the number and intensity of informal actions, which are difficult for state and management to control even during the economic crisis. For example, insubordination seems not only to have increased during the crisis, it is also more frequently accompanied by insults and assaults on supervisory staff.

\section{Women Pluckers and the Maximization of Labour Productivity}

In January 1987 the management and the union leadership agreed on an increase in task quotas from 26 to $32 \mathrm{~kg}$ of green leaves. While the new norms were implemented on the two other CDC tea estates in June-July 1987, women pluckers on the Tole Estate continued to resist this decision. Eventually the CDC General Manager personally called on the union leadership to persuade the Tole pluckers to accept the decision. It was not until October that the Tole pluckers reluctantly accepted the increase in task work at a mass meeting organized by the union.

One year later, on 3 October 1988, the Tole pluckers went on strike. They argued that they were unable to fulfil the new task requirement, even though they worked from 6.30 a.m. to 6.00 p.m. every day. The union president strongly condemned their strike action, saying that it was illegal because they had not followed the prescribed procedures for settling conflicts. He was booed and jeered by the angry 
women. The CDC General Manager then threatened the strikers with dismissal if they did not report for work the next day, with the result that most women decided to resume work. Seventy-nine continued striking, and they were summarily dismissed. Many of them stayed in the area afterwards, surviving on farming and trading.

No further collective actions on this issue have been reported. There is some evidence, however, that the pluckers increasingly resort to informal actions to protest against the managerial attempts to raise labour productivity. Estate reports suggest that since the onset of the crisis there has been a rise in various forms of informal resistance, such as late arrival at work, absenteeism, malingering and poor work performance. The rate of absenteeism in particular has caused concern in management circles. Women tend to be absent from work more often than men because of their multiple responsibilities outside the workplace. The estate manager reported to the union that absenteeism could be blamed for the loss of over 1,700 persondays during the months July-August 1992 . He estimated the corporation's financial loss from this at about FCFA 11 million. He warned the union president that he would not hesitate to dismiss over a hundred workers if the union and shop stewards failed to address this situation. ${ }^{6}$ Apparently the managerial crusade against 'undisciplined and unproductive' workers had not been successful during the crisis.

\section{Women Pluckers and Intensified Managerial Control}

Supervisory staff constitute an essential link between the estate management and the workers. They are expected to communicate management orders to the workers and to maintain discipline in the workplace. While the command structure on the estate has remained male-dominated, one may observe a change in the gender composition of the supervisory staff in the female-dominated plucking section. The position of overseer was formerly monopolized by men, but the position of head of the separate labour gangs was open to women at an early stage. Gradually some women were appointed overseer and even senior overseer. Despite this change, problems of control have persisted.

Since the onset of the economic crisis there has been enormous management pressure on the supervisory staff to exercise tight control over their subordinates, to use their authority to the full and, if necessary, to discipline any worker without compassion. The increasingly authoritarian and overzealous supervision appears not to have had the desired effect of strengthening managerial control at the workplace. It seems instead to have antagonized the women, making them feel like slaves, incessantly prodded to increase production without reward. Although there used to be numerous collective actions aimed at the transfer or dismissal of 
unpopular supervisors, such actions abated during the economic crisis. The women seem to have realized that such actions not only are risky, but they will almost certainly be ineffective. With management actively encouraging strict supervision during the crisis, it is not likely to give in to collective demands from the workers for supervisors' removal.

However, there does seem to be widespread informal resistance against intensified managerial control. It manifests itself in various forms, including:

\section{Insubordination}

It is not uncommon for women to simply refuse to carry out orders from their supervisors, even if such a refusal might result in considerable loss of output. For instance, some women refuse to do overtime on Saturdays during the peak plucking season, as they see Saturday afternoons as a period for working on the food farms, trading and washing clothes. Estate records suggest that insubordination is increasingly accompanied by insults and abuse, and even physical attacks on supervisory staff.

\section{Attempts to discredit supervisory staff}

At tımes, women try to play tricks on supervisors and to discredit them with their superiors. This often takes the form of falsely accusing them of bribery, corruption and other misdeeds, in the hope that management will take action against them.

\section{The threat of using mystical powers}

Women sometimes threaten to harm or kill a supervisor by sorcery and witchcraft. It is hard to know whether this is mere bluff or a real threat.

\section{Women Pluckers and Minimization of Wages and Other Conditions of Service}

Women pluckers have always fought for improvement in their living standards, and they have steadfastly resisted any managerial effort to curtail their wages and fringe benefits. It is little wonder, then, that they were enraged about the 6 January 1990 agreement between management and union leadership which introduced a compulsory savings scheme and brought about a drastic reduction in their fringe benefits. Therr bitterness was reflected in a collective action two years later.

In early 1992, Tole women pluckers, together with workers on other CDC estates, began agitatıng for the abrogation of this agreement and the immediate payment of seven quarters' family allowance arrears. When the management tried to employ delayıng tactics, they went on strike from 21 to 26 May 1992. As a result of this strike, the management agreed to various amendments to the agreement, including 
the re-introduction of free accommodation and water, as well as a 24 per cent reduction in medical costs.

In addition to this collective action, women pluckers have engaged in many kinds of informal actions in protest against low remuneration. These have included output restriction, sabotage and involvement in 'illegal' income-generating activities. Some women do not keep to the plucking standards. They add bad leaves to the good ones, a practice which enables them to complete their task earlier and to achieve more weight and income. Others steal tea from the factory and sell it to middlemen. The management frequently complains that the theft of tea has reached unprecedented levels since the economic crisis and has caused serious losses to the company. Still other women cut tea bushes and pruning to use them for firewood. These and other 'illegal' activities are not only expressions of protest, but also they provide welcome supplements to the women's meagre incomes.

\section{Conclusion}

In this study I have attempted to show that plantation work plays an ambivalent role in the lives of women tea pluckers in Cameroon. It has positive meanings for them in that it enables women, especially those who are illiterate and 'husbandless', to escape patriarchal controls in their local communities and achieve a relatively autonomous existence. As household heads, they are highly dependent on plantation work for the reproduction of their families, and they display a high commitment to their job. But the work also has negative consequences. It is very tedious and poorly paid, and it is unlikely to foster much job satisfaction. It requires so much energy and time that the women have difficulty coping with their other roles outside the workplace. Above all, it fails to provide them with adequate income, and it offers few prospects for promotion and social advancement. These negative features are little conducive to labour productivity, and they pose problems of labour control.

Tole women have never acquiesced in control and exploitation in the workplace. They have engaged in various modes of resistance, thus challenging the common managerial assumption that female workers in developing countries are easier to control than male workers. Women plantation workers in other African countries have demonstrated a similar capacity to defend their interests against employers. Presley (1986) reports that Kikuyu women employed on settler farms in Kenya were involved in labour protests from the 1920s to the 1960s. With a persistent series of work stoppages and strikes, mostly aimed at improving wages and working conditions, these women gained confidence in the power of their collective efforts. This power was reinforced by the heightened political militancy of post-war Kenya. Research on the agro-industrial plantations of Bud in Senegal (Kane 1977; Mackintosh 1989) and in Nigeria (Jackson 1978) has highlighted women's 
involvement in various forms of action. Class-oriented struggles of women plantation workers have also been reported in Tanzania (Mbilinyi 1988).

This study provides evidence that the majority of the Tole female pluckers have not abandoned their 'traditional' militancy even during the economic crisis, and that they continue to engage in (sporadic) collective actions and (frequent) informal actions to protest against their intensified exploitation and subordination in the workplace. A number of factors appear to account for their ongoing resistance. One of these is their remarkable solidarity. The various internal divisions among the women never seem to have impeded them from undertaking common actions against the employer, though it cannot be denied that their solidarity has been somewhat weakened by the present economic crisis. This solidarity has been fostered by their residing in an 'occupational community' where they share similar living and working conditions, speak one lingua franca (Pidgin English), and can easily communicate with each other. These poorly educated women have always put less faith in the institutionalized bargaining procedures than the more moderate union leadership, which is composed mainly of male clerks and supervisory staff. The repeated failure of such procedures to achieve workers' aims, together with the establishment of state control over the unions, has strengthened this belief in militant action as the only way to bring management to its knees and redress longstanding grievances.

The growing demotivation of many women during the crisis has also played a role in the rising militancy. Far from being rewarded for their higher productivity by increased wages, women have seen their real incomes seriously eroded. Most women are still reluctant to resign and forfeit their regular monthly wage income, however meagre; but a growing number of women are no longer interested in keeping their job at any cost, especially since they have also lost confidence in the corporation's eventual economic recovery. Some have already resigned, collecting their long-service awards and gratuities as well as their voluntary and compulsory savings. They then invest this capital in farming, trading, and other potentially lucrative activities. Others are still contemplating resignation. No longer committed to their job, they tend to become either more militant and less reluctant to offer resistance, or more apathetic, having thought out their alternatives.

Another factor influencing women's attitude is their daily exposure to the glaring socioeconomic inequalities on the estate. Although the corporation's adjustment measures have effected a sizable reduction in the high salaries and numerous fringe benefits of the managerial staff, there remains an immense gap in incomes and living standards between them and the workers. There is no doubt that women's intense feelings of exploitation and subordination are reinforced by the blatant contrast between their own misery and managerial opulence.

The management has failed to fully control women's resistance during the crisis. There is no reason to believe it will succeed in doing so in the near future. Much to 
the contrary, there are indications that labour resistance may even be on the increase. Recently the unions regained most of their former autonomy, and the union leadership has grown more critical of the adjustment measures that it had previously agreed on with management. CDC workers have traditionally admired militant union leadership, and they will be inclined to support union actions in defence of their interests.

\section{Notes}

1. My research on women pluckers was part of a larger project on plantation labour in Anglophone Cameroon. Between 1985 and 1993 I regularly visited the Tole Tea Estate.

2. FCFA 100 is equal to French Franc 1.

3. See Report of the Consultative Meeting with the Ministry of Labour and Insurance at Provincial Level by Mr. P.M. Kamga, dated 28 October 1989, in File MEPS/SWP/ BU.134, Vol. IV, General Correspondence CDC.

4. Report of the Conciliatory Meeting between CDC Management and Tole tea workers on 25 November 1976, in File MEPS/SWP/BU.124/S.2, Industrial Trade Disputes-CDC.

5. See CDC, Tole Tea Estate, Minutes of Estate Consultative Meeting held at the Club on 13 October 1990.

6. See letter from Mr. R.M. Achiri, Estate Manager Tole Tea, to President Agricultural Workers' Union, dated 16 September 1992, in File MTPS/IDTPS/SWP/LB.2/Vol. XXVII, Complaints from CDC. 